\title{
Short Communication \\ The ghost of climatic change in the geographic distribution of Tillandsia aeranthos (Bromeliaceae)
}

\author{
Elián Leandro Guerrero ${ }^{1,2,3,4}$
}

\begin{abstract}
The geographic distribution of Tillandsia aeranthos is updated with new records. Its southern limit is extended 200 kilometers in a zone previously studied by many botanists and naturalists, but also in poorly explored areas. For this reason, the possibility that the change in distribution is recent is postulated and discussed. The coincidence of this change with the southward shift in the isohyets and the decrease of winter frost frequency are highlighted as a possible cause of the advance to the south. In addition, two petal color variants of this species are first mentioned for Argentina. The new findings display that it is necessary to further explore some dry forests of eastern Buenos Aires and study the possible consequences of the climatic change in the biota of South America.

Key words: climatic change, conservation, flower color variants, ornamental Bromeliaceae, Pampas, xerophytic forest.

\section{Resumen}

Se actualiza la distribución geográfica de Tillandsia aeranthos con nuevos registros. Su límite austral se extiende 200 kilómetros en una zona previamente estudiada por numerosos botánicos y naturalistas, pero también en áreas poco exploradas. Por esta razón, se postula y discute la posibilidad de que el cambio en la distribución sea reciente. Se remarca la coincidencia entre este cambio con el corrimiento de las isohietas y el descenso en la frecuencia de heladas invernales como una posible causa del avance hacia el sur. Adicionalmente, dos variantes de color de flor de esta especie son mencionadas por primera vez para Argentina. Los nuevos hallazgos muestran que es necesario explorar con más énfasis algunos bosques secos del este de Buenos Aires y estudiar las posibles consecuencias del cambio climático en la biota de Sudamérica.

Palavras-chave: cambio climático, conservación, variantes de color de flor, Bromeliaceae ornamentales, Pampa, bosques xerófilos.
\end{abstract}

Climatic change is considered as one of the mayor drivers of species' distribution shifts worldwide, producing area expansions or retractions and leading to deep changes in ecosystem properties (McCarty 2001; Walther et al. 2002; Parmesan 2006; Walther 2010; Hickling et al. 2006; García Molinos et al. 2018). The consequences of these processes on the biota were mainly studied in the northern hemisphere (Parmesan 2006). However, in the last decade there was an increase in works about climatic change and its ecological consequences in South America. Several publications focused on how some species' distributions may change facing future climate scenarios (e.g., Nori et al. 2014; Medone et al. 2015; Ferretti et al. 2018; Silva Vieira et al. 2018; Silva et al. 2018), while others showed

\footnotetext{
${ }^{1}$ Universidad de La Plata, Facultad de Ciencias Naturales y Museo, División Plantas Vasculares, Museo de La Plata, Paseo del Bosque s/n, 1900 La Plata, Argentina.

${ }^{2}$ CONICET - Consejo Nacional de Investigaciones Científicas y Técnicas, Godoy Cruz 2290, C1425FQB Ciudad Autónoma de Buenos Aires, Argentina.

3 ORCID: <https://orcid.org/0000-0002-7660-4340>

${ }^{4}$ Author for correspondence: eguerrero@fcnym.unlp.edu.ar
} 
that range shifts of numerous species in the past century were probably a consequence of climate changes (e.g., Serrentino et al. 2014; Guerrero \& Agnolin 2016).

In eastern Buenos Aires province, Argentina, an increase in average rainfall amounts since 1960 shifted the isohyets an average distance of $100 \mathrm{~km}$ towards the south and west (Sierra et al. 1994; Berbery et al. 2006; Barros et al. 2015; Fig. 1), and the mean annual temperature increased about 0.5 ${ }^{\circ} \mathrm{C}$, so that the isotherms shifted $50 \mathrm{~km}$ southwards (Barros et al. 2015). Additionally, winter frost frequency decreased in some parts of the territory (Fernández Long \& Müller 2006). A poleward shift in species distribution was found in 44 species of plants, 33 butterflies, 25 birds, eight arachnids, three mammals, and three turtles, coinciding with the direction that would be expected if these changes were climate-driven (Guerrero \& Agnolin 2016; Delaloye 2017). Around $74 \%$ of the abovementioned plant species showed a shift of about the same magnitude of the isohyet and isotherm displacements (Guerrero \& Cellini 2017). Such changes were also reported for the tetrapod fauna of eastern Uruguay, where similar modifications in precipitation and temperature mean values were measured. The mean annual rainfall increase during the last century in this country had probably enabled the mammals Cabassous tatouay and

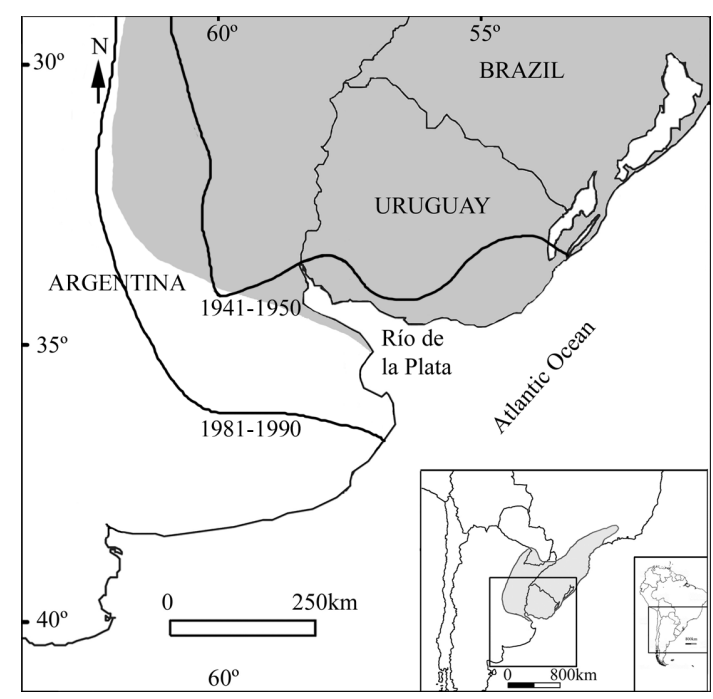

Figure 1 - Map showing the study area and the shift of the 1,000 mm isohyet between the 1940-1950 and 1981-1990 decades (modified from Sierra et al. 1994). In gray, approximate south limit of distribution of Tillandsia aeranthos.
Tamandua tetradactyla, the crocodilian Caiman latirostris and the amphibian Scinax uruguayanus to colonize southern areas (Serrentino et al. 2014; Villalba et al. 2018). Other striking findings in the Pampean plains and surrounding areas were also found to be climate driven range shifts, such as the presence of the mammals Dasypus novemcinctus (Zamorano \& Scillato-Yané 2008) and Hydrochoerus hydrochaeris (Doumecq-Milieu et al. 2012) in southern Buenos Aires province, the opossum Didelphis albiventris in northern Patagonia (Carrera \& Udrizar Sauthier 2014), some insects in southeastern Buenos Aires (Farina 2006), the monkey Alouatta caraya in northern Uruguay (Prigioni et al. 2018), and some birds in Rio Grande do Sul (Franz et al. 2018).

Bromeliaceae, the "pineapple" family, is a characteristic family of the Neotropical Region (Cabrera \& Willink 1973), with only a few species in temperate Chile (Zizka et al. 2009) and one in the Guinea region of western Africa (Porembski \& Barthlott 1999). Tillandsia L. is its most species-rich genus, with at least 623 (Barfuss et al. 2016) or as much as 747 species (Gouda et al. continuously updated). Tillandsia aeranthos (Loisel.) L.B.Sm. is an epiphytic species (Fig. 2a), and occasionally epipetric species (Wanderley \& Martins 2007; Melo \& Waechter 2018), which usually presents bright pink bracts and sepals and deep blue corolla (Fig. 2b). These beautiful colors combined with easy cultivation, turned this species into a popular ornamental plant for growers and gardeners around the world (Oeser 1965; Reitz 1983; Reilly 2004), as many other bromeliads. It is also the most popular epiphytic species grown in gardens of Argentina (Mongiello \& Otero 2017).

The native distribution area of Tillandsia aeranthos ranges from São Paulo (Brazil) to the Río de la Plata region (Uruguay-Argentina) and from the Atlantic seashore to the Humid Chaco (ParaguayArgentina) (Smith \& Downs 1977; Wanderley \& Martins 2007). According to the biogeographical scheme of Cabrera \& Willink (1973) the occurrence of Tillandsia aeranthos encompasses the Paranaean, Atlantic, Espinal, Chaco, and Pampean provinces, occurring from moist forests of the Paranean province to thorn woodlands of the Espinal province and gallery forests of the Pampean province.

In Brazil, Tillandsia aeranthos was found in São Paulo, Santa Catarina and Rio Grande do Sul (Reitz 1983; Wanderley \& Martins 2007; Forzza et al. 2015); in Paraguay there are few records in the eastern part of the country (Smith 
\& Downs 1977); the species occurs throughout Uruguay (Smith 1972); in Argentina the species was mentioned for the more northern provinces Corrientes, Chaco, Misiones, Entre Ríos, Santa Fe and Buenos Aires (Schinini et al. 2008). Several citations for Catamarca, Jujuy, Salta, Santiago del Estero, Tucumán, and Córdoba (Schinini et al. 2008), were not proved with any specimen. The southern limit of this species was the gallery forest of the Río de la Plata, at $35^{\circ}$ south latitude (Smith \& Downs 1977; Cabrera 1968; Fig. 1). It is one of the species of the subgenus Anoplophytum that reaches the highest latitudes, together with $T$. bergeri.

During fieldworks in some sites of the Pampean biogeographical province, I found new records of Tillandsia aeranthos which enlarge considerably its distributional range to the south. Therefore, the main objective of this work is to update the distribution of this species using these records and herbarium specimens, and to discuss the possibility that the geographic expansion of the species is recent and climate related.
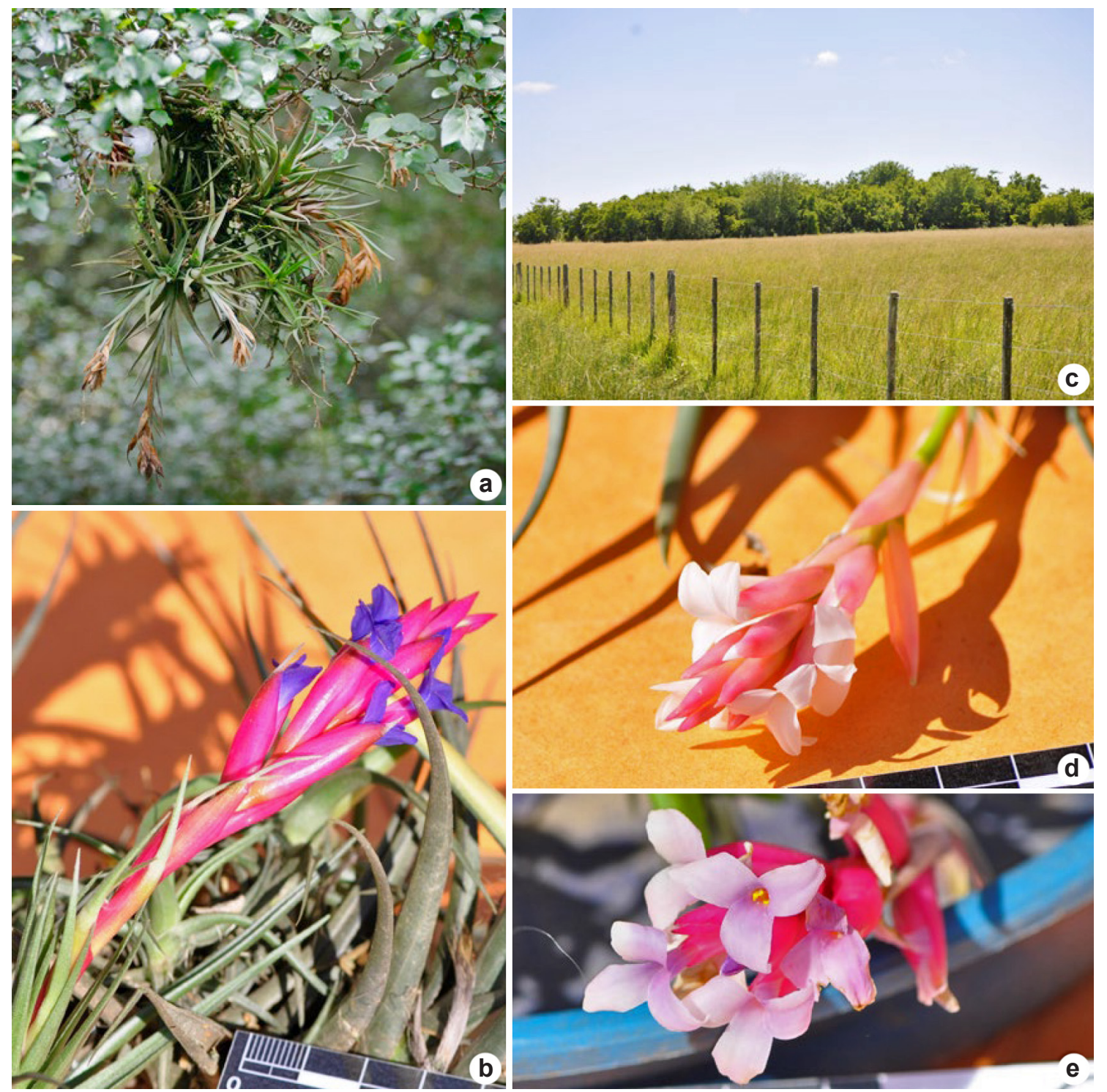

Figure 2 - a-e. Tillandsia aeranthos - a. in habitat, on Celtis tala forest in Laguna La Escondida, Dolores; b. detail of a typical T. aeranthos flower; c. a view of a Celtis tala forest from eastern Buenos Aires province; d. T. aeranthos flower color variation with white petals; e. T. aeranthos flower color variation with pink petals. 
Fieldtrips were conducted to several localities of Buenos Aires province, aiming to collect specimens of Tillandsia aeranthos. Most sites are xerophytic forests dominated by Celtis tala Gillies ex Planch. (Cannabaceae), locally known as "talares" (Fig. 2c).

The acronyms of the revised herbaria agree with Thiers (continuously updated). Dried specimens of Tillandsia aeranthos from the Museo de La Plata (LP) and the Museo Argentino de Ciencias Naturales (BA) herbaria were studied. Besides these dried samples, fifty living specimens from different locations of the study area were used for comparison.

Several varieties of $T$. aeranthos were described from southern Brazil (Strehl 2000, 2004; Strehl \& Rohde 1998). All the non-typical varieties inhabit forests and urban sites in Rio Grande do Sul state (Martinelli et al. 2008; Varella 2011; Gouda et al. continuously updated). The taxonomy of these infra-specific taxa is still debatable, so, in accordance with Schinini et al. (2008) and BFG (2018), the flower color variations of $T$. aeranthos were not considered as valid taxonomic units in this work to avoid confusion.

The following new records of Tillandsia aeranthos extend the distribution range $200 \mathrm{~km}$ to the south (Fig. 3). The southernmost collection sites are Villa Gesell and the Celtis tala forests of General Madariaga, and it is also a common epiphyte in Dolores and Chascomús districts occurring on the same phorophyte.

Examined material: ARGENTINA. BUENOS AIRES: Vieytes, Ruta 36, Magdalena, 26.X.2004, S. Torres Robles 1718 (LP); Chascomús (3534.731'S, $\left.58^{\circ} 0.840^{\prime} \mathrm{W}\right)$, epiphyte on many trees of the park and streets, 29.VIII.2018, E.L. Guerrero 725 (LP); Talar de Estancia Rincón de López, 13.X.2002, S. Torres Robles 897 (LP); 27.X.2004, S. Torres Robles 1892 (LP); Loma de la Reducción, Castelli, Calcagno (coll.) (LP); Reserva Natural Laguna Salada Grande, 28.X.2004, S. Torres Robles 1834 (LP); Villa Gesell (37 $7^{\circ} 15.016$ 'S, $56^{\circ} 57.849^{\prime} \mathrm{W}$ ), epiphyte on Pinus sp. $2.5 \mathrm{~m}$ high, 29.VII.2017, E.L. Guerrero 696 (LP); Paisaje Protegido Arroyo El Pescado, La Plata, on Celtis tala, 26.X.2015, E.L. Guerrero 568 (LP); 26.X.2015, E.L. Guerrero 569 (LP); Divisadero Station, General Madariaga, on Celtis tala, 3.I.2020, E.L. Guerrero 798 (LP); road to Juancho, General Madariaga, on Celtis tala, 4.I.2020, E.L. Guerrero 800 (LP).

Additional examined material: ARGENTINA, BUENOS AIRES: San Pedro, Refugio Histórico y Natural "Vuelta de Obligado", 28.X.2003, S. Torres Robles 1574 (LP); X.2004, S. Torres Robles 2284 (LP). Baradero, Estancia Los Álamos, Fundación Figueroa
Salas, 27.X.2003, S. Torres Robles 1428 (LP). Campana, Reserva Natural Estricta Otamendi, 1.XI.2004, S. Torres Robles 2065 (LP); Otamendi, 23.X.1976, Fernández Viloso (BA). Isla Martín García, 30.X.2004, S. Torres Robles 2016 (LP); XI.1950, A. Castellanos (BA); 12.X.1921, A. Castellanos (BA); 26.X.1948, $W$. Partridge (BA). Ramallo, Estancia Cuini, 29.X.2003, S. Torres Robles 1637 (LP). San Isidro, 21.X.1928, R.L. Pérez Moreau (BA); XI.1924, A. Castellanos (BA); Barracas al Sud [old name for Avellaneda], 08.XI.1902, S. Venturi 237 (BA). Quilmes, IX.1914, A. Orlando (LP); Bernal, 02.IV.2015, E.L. Guerrero 531 (LP); 28.XII.2015, E.L. Guerrero 582 (LP). La Plata, Parque Ecológico, 20.IX.1995, G. Delucchi 1024 (LP); talar del Arroyo el Pescado, cerca de Villa Garibaldi, 20.XII.2015, E.L. Guerrero 574 (LP); cerca de Villa Garibaldi, 20.XII.2015, E.L. Guerrero 575 (LP); 20.XII.2015, E.L. Guerrero 576 (LP); Ensenada, Punta Lara, 30.X.1932, A.L. Cabrera 2436 (LP); 01.XI.1929, A. Castellanos (BA); 01.VI.1929, R.L. Pérez Moreau (BA); Ensenada, C.L. Spegazzini 201 (LP). Berisso, Los Talas, 16.X.1932, A.L. Cabrera 2358 (LP). San Nicolás, 12.X.1941, A.L. Cabrera 7187 (LP). ENTRE RÍOS: Villaguay, Arroyo Villaguay, puente Urquiza viejo, 17.X.1981, O. Bottino 7 (LP). SANTA FE: Rosario, Arroyo Frías, 06.X.1929, A.L. Cabrera 921 (LP). URUGUAY. COLONIA: Riachuelo, 11.X.1936, A.L. Cabrera 3824 (LP); X.1949, H. Fabris 67 (LP).

The species was also observed in the following sites: Bahía de Samborombón, Chascomús district, on Celtis tala; Laguna Monasterio, Chascomús district, on Celtis tala forest; Santa Teresita, La Costa district, on Pinus

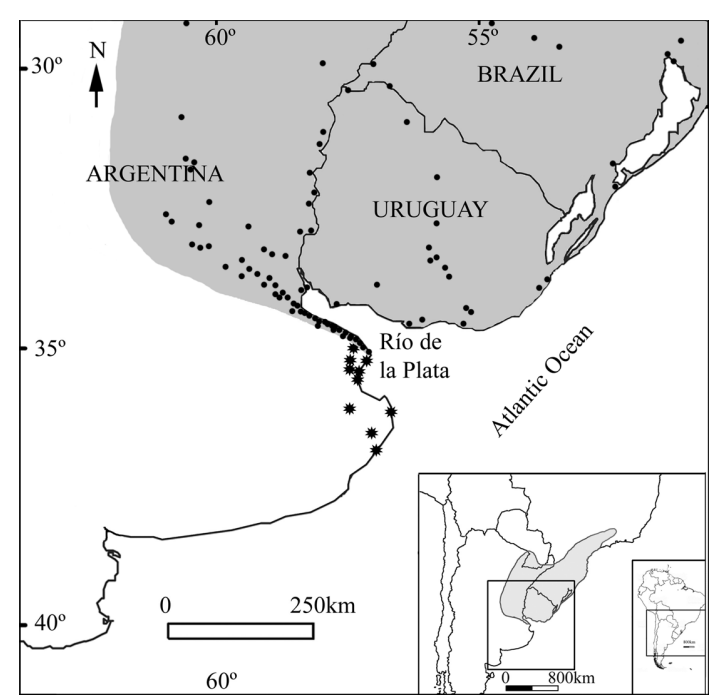

Figure 3 - Map showing the new records of Tillandsia aeranthos (stars). Points: previous records. In gray: approximate south limit of distribution of the species. 
sp.; and Laguna La Escondida, Dolores district, on Celtis tala forests (Fig. 2a).

Some Tillandsia specimens with pink or white petals, and pink bracts were found on Celtis tala in an isolated forest over the small cliff that limits the floodplain to the north side of the El Pescado Creek (34 $59,854^{\prime}$ 'S, 57 $499,092^{\prime}$ W). Some specimens bear pink floral bracts and pink petals (e.g., Guerrero 569; Fig. 2e), while others have white petals (e.g., Guerrero 568; Fig. 2d). These white-petal specimens have also longer petals than the typical T. aeranthos (2.66-2.8 vs 1.7-2.7) and longer floral bracts. Using the species keys (Cabrera 1968; Smith 1970; Smith \& Downs 1977) these specimens seemed to fall into T. bergeri based on the distinctive flower color. However, the filament plication, and the length of petals and anthers agree with those of $T$. aeranthos. These are the first records of flower color variations of Tillandsia aeranthos in Argentina.

The new occurrence records of Tillandsia aeranthos may indicate that the species follows the Celtis tala forests from the Río de la Plata to General Madariaga, but it may range farther to the south in these forests that, according to Parodi (1940), extend to $37^{\circ} 55^{\prime} \mathrm{S}$. As cultivated trees in parks and streets are well suitable for this species, it may be expanding from the native forests to cities and tree plantations, as seen in La Costa district and in Villa Gesell.

Taking into account that the east part of Buenos Aires province was studied by many botanists during the last century (e.g., Cabrera 1936, 1941, 1963-1970; Vervoorst 1967; Frangi 1975; Faggi \& Cagnoni 1991), it is quite noteworthy why this ornamental bromeliad was not detected previously. It seems unlikely that this plant passed unadvertised by so many botanists. Two other possible explanations are: 1) the plants inhabited isolated unexplored forests and expanded to rural areas and cities in the last decades; 2) the species advanced to the south in recent years following climate warming.

It might be questionable to propose a climate change-related expansion since there are still unexplored forests in Buenos Aires (i.e., isolated forests in La Postrera, El Tordillo, General Lavalle, etc.). We have scarce (or none) collections in herbaria or other museum repositories from these forest sites of eastern Buenos Aires. There are many works reporting new findings of bromeliads in poorly explored regions in south Brazil and northern Argentina (e.g., Magalhaes et al. 2014;
Miyamoto \& Tardivo 2014; Büneker et al. 2015; Lima \& Soares-Silva 2016; Guarçoni et al. 2018). However, the southern localities here reported, and their surroundings were explored in detail by the botanist A.L. Cabrera (Cabrera 1936, 1941), and he didn't collect neither mentioned Tillandsia aeranthos. Furthermore, Parodi (1940) didn't mention this species when he addressed the forest composition of the talares between General Madariaga and Villa Gesell (the southern sites presented in this contribution), but remarked the presence of an epiphytic Blechnum sp., showing that he paid attention to the epiphytic plants. This can tilt the balance towards the idea of a consequence of climate change.

An emblematic case in the same area is the range expansion of the butterfly Morpho catenarius which was well documented by J. Farina (2006). The feeding plant of the larvae (analogue of the phorophyte for $T$. aeranthos) is Scutia buxifolia, a tree that grows in the region since centuries (Delucchi \& Charra 2012), and so Farina (2006) proposed that the expansion of the butterfly should be related to the loss of a barrier, probably a climatic one. Most of the ecological conditions that Morpho catenarius or Tillandsia aeranthos needed to colonize the southern Celtis tala forests already existed in the area before their arrival for both (i.e., forest vegetation, vertical structure, absence of competitors, low density of predators/herbivores, etc.). But only in the last decades both species apparently advanced to the south, coinciding with the shift of the isohyets (see Sierra et al. 1994; Sierra \& Pérez 2006; Berbery et al. 2006). A similar case probably took place with the expansion of another butterfly, Theochila maenacte maenacte, which advanced $300 \mathrm{~km}$ to the south in the area in recent years (Nuñez Bustos 2016). Even more, the talares and some birds that feed and nest on them (Cyanocompsa brissonii, Icterus cayanensis, Lepidocolaptes angustirostris, pachyramphus polychopterus and Paroaria capitata) extended to the south in about $100 \mathrm{~km}$ (Chimento et al. 2012). This shift is possibly related to human modifications in the landscape, because these birds use groves to rest and then disperse the Celtis tala seeds (Chimento et al. 2012), but also to the climatic changes that allowed these birds to breed and nest in southern sites. A similar case is discussed in Apodaca \& Guerrero (2019) for the expansion of Tillandsia recurvata in Buenos Aires province, which was frequently observed within implanted groves instead of natural environments. 
Wetland species from north and northeast Buenos Aires province, such as trees (e.g., Enterolobium contortisiliquum), bushes (e.g., Mimosa pigra), herbs (e.g., Doryopteris pentagona), climbers (e.g., Araujia angustifolia) and epiphytes (e.g., Pleopeltis pleopeltifolia), and many animals like birds (e.g., Anhinga anhinga), mammals (e.g., Cerdocyon thous), reptiles (e.g., Phrynops hilarii), spiders (e.g., Nephila clavipes), harvestmen (e.g., Metalibitia argentina) and butterflies (e.g., Hamadryas februa), were also possibly favored by the observed increase of rainfall in the area (Guerrero \& Agnolin 2016; Guerrero \& Cellini 2016). In the same way, some species that require forested physiognomies (e.g., Chacoan birds, insects, and Tillandsia aeranthos) may be advancing to the south across the xerophytic forests, colonizing new areas of eastern Buenos Aires as humidity and temperature increase.

The possibility of a range expansion related to a climatic change must be considered for Tillandsia aeranthos. The new findings indicate the importance to study the possible consequences of the climatic change in the biota of South America. The new records of $T$. aeranthos also show that some of the eastern Buenos Aires xerophytic forests must receive more attention from a biodiversity conservation standpoint.

\section{Acknowledgments}

Thanks to P. Carrión for her help during the field trips; also, to L.F. Varella Klein for his help with the bibliography, commentaries and photographs of Brazilian specimens; to C.M. Prigioni for sending me some papers; to L. Katinas, J.V. Crisci and R. Jabaily who read an early version of this text; and to the reviewers of Rodriguésia, whose commentaries improved the manuscript.

\section{References}

Apodaca MJ \& Guerrero EL (2019) ¿Por qué se expande hacia el sur la distribución geográfica de Tillandsia recurvata (Bromeliaceae)? Boletín de la Sociedad Argentina de Botánica 54: 255-261.

Barfuss MH, Till W, Leme EH, Pinzón JP, Manzanares JM, Halbritter H, Samuel R \& Brown GK (2016) Taxonomic revision of Bromeliaceae subfam. Tillandsioideae based on a multi-locus DNA sequence phylogeny and morphology. Phytotaxa 279: 1-97.

Berbery EH, Doyle M \& Barros V (2006) Tendencias regionales en la precipitación. In: Barros V, Clarke R \& Silva Días P (eds.) El cambio climático en la
Cuenca del Plata. CONICET, Buenos Aires. Pp. 67-79.

BFG - The Brazil Flora Group (2018) Brazilian Flora 2020: innovation and collaboration to meet Target 1 of the Global Strategy for Plant Conservation (GSPC). Rodriguésia 69: 1513-1527.

Büneker HM, Pontes RC \& Witeck-Neto L (2015) New records in Tillandsia L. (Bromeliaceae, Tillandsioideae) for Rio Grande do Sul, Brazil. Rodriguésia 66: 493-498.

Cabrera AL (1941) Las comunidades vegetales de las dunas costaneras de la Provincia de Buenos Aires. DAGI Publicaciones técnicas 1: 5-44.

Cabrera AL (1963-1970) Flora de la provincia de Buenos Aires. Instituto Nacional de Tecnología Agropecuaria, Buenos Aires. 3213p.

Cabrera AL (1968) Bromeliaceae. In: Cabrera AL (ed.) Flora de la Provincia de Buenos Aires, parte 1. Instituto Nacional de Tecnología Agropecuaria, Buenos Aires. Pp. 448-459.

Cabrera AL \& Willink A (1973) Biogeografía de América Latina. Organización de los Estados Americanos Serie Biología, Monografía 13, Washington. 122p.

Cabrera AL (1936) Apuntes sobre la vegetación de las dunas de Juancho. Notas del Museo de La Plata, botánica 1: 207-236.

Carrera M \& Udrizar Sauthier DE (2014) Enlarging the knowledge on Didelphis albiventris (Didelphimorphia: Didelphidae) in northern Patagonia: New records and distribution extension. Historia Natural, tercera Serie 4: 111-115.

Chimento NR, Agnolin FL, Guerrero EL, López AM \& Lucero RF (2012) Nuevos registros de aves y consideraciones sobre la extensión geográfica de los talares al sur de la provincia de Buenos Aires. Nótulas Faunísticas 89: 1-12.

Delaloye M (2017) El Anó Grande Crotophaga major en Atalaya, provincia de Buenos Aires, Argentina: ¿estaría extendiendo su distribución hacia el sur? Cotinga 39: 110-112.

Delucchi G \& Charra GR (2012) La flora y vegetación pampeanos vistas por los cronistas y viajeros de los siglos XVIII y XIX. Historia Natural, tercera serie 2: 73-83.

Doumecq-Milieu RE, Morici A \& Nigro NA (2012) Ampliación de la distribución austral del carpincho (Hydrochoerus hydrochaeris) en la provincia de Buenos Aires, Argentina. Nótulas Faunísticas 92: 1-10.

Faggi AM \& Cagnoni M (1991) La vegetación de Punta Rasa (Pcia. de Buenos Aires. Argentina). Parodiana 6: 363-374.

Farina JL (2006) Insectos asociados al tala (Celtis tala), en el límite sur del espinal. In: Mérida E \& Athor J (eds.) Talares bonaerenses y su conservación. Fundación de Historia Natural Félix de Azara, Buenos Aires. Pp. 166-172. 
Fernández Long ME \& Müller GV (2006) Annual and monthly trends in frost days in the Wet Pampa. Proceedings of 8 ICSHMO. April 24-28, 2006. INPE, Foz do Iguaçu. Pp. 249-253.

Ferretti NE, Arnedo M \& González A (2018) Impact of climate change on spider species distribution along the La Plata River basin, southern South America: projecting future range shifts for the genus Stenoterommata (Araneae, Mygalomorphae, Nemesiidae). Annales Zoologici Fennici 55: 123133.

Forzza RC, Costa A, Siqueira Filho JA, Martinelli G, Monteiro RF, Santos-Silva F, Saraiva DP, PaixãoSouza B, Louzada RB \& Versieux L (2015) Bromeliaceae. In: Lista de Espécies da Flora do Brasil. Instituto de Pesquisas Jardim Botânico do Rio de Janeiro, Rio de Janeiro. Available at $<$ http://floradobrasil.jbrj.gov.br/jabot/floradobrasil/ FB6362>. Access on 30 August 2018.

Frangi J (1975) Sinopsis de las comunidades vegetales y el medio de las sierras de Tandil (provincia de Buenos Aires). Boletín de la Sociedad Argentina de Botánica 16: 293-318.

Franz I, Agne CE, Bencke GA, Bugoni L \& Dias RA (2018) Four decades after Belton: a review of records and evidences on the avifauna of Rio Grande do Sul, Brazil. Iheringia, Série Zoologia 108: e2018005.

García Molinos JG, Poloczanska ES, Olden JD, Lawler JJ \& Burrows MT (2018) Biogeographical shifts and climate change. In: Dellasala DA \& Goldstein MI (eds.) Encyclopedia of the Anthropocene. Elsevier, Oxford. Pp. 217-228.

Gouda EJ, Butcher D \& Gouda CS [continuously updated] A list of accepted Bromeliaceae names. Utrecht, University Botanic Gardens. Available at $<$ http://bromeliad.nl/encyclopedia/>. Access on 9 July 2020.

Guarçoni EA, Costa AF, Silva EO, Ferreira AW, Oliveira MS \& Costa AF (2018) New records of Tillandsia L. (Bromeliaceae, Tillandsioideae) for Maranhão state, Brazil. Check List 14: 951-959.

Guerrero EL \& Agnolin FL (2016) Recent changes in plant and animal distribution in the southern extreme of the Paranaense biogeographical province (northeastern Buenos Aires province, Argentina): ecological responses to climate change? Revista del Museo Argentino de Ciencias Naturales 18: 9-30.

Guerrero EL \& Cellini JM (2017) Corrimiento del límite austral de distribución geográfica en tres especies del género Pleopeltis (Polypodiaceae) en la provincia de Buenos Aires (república Argentina) y su posible relación con el cambio climático. Cuadernos de Investigación UNED 9: 51-58.

Hickling R, Roy DB, Hill JK, Fox R \& Thomas CD (2006) The distributions of a wide range of taxonomic groups are expanding polewards. Global Change Biology 12: 450-455.
Lima JHD \& Soares-Silva LH (2016) Two new records for Bromeliaceae in the central-west region of Brazil: Vriesea friburgensis and Tillandsia polystachia. Rodriguésia 67: 1093-1100.

Magalhães R, Versieux LM \& Calvente A (2014) Aechmea muricata (Arruda) LB Sm. (Bromeliaceae: Bromelioideae): a new record of a threatened species for Rio Grande do Norte, northeastern Brazil. Check List 10: 434-435.

Martinelli G, Vieira CM, Gonzalez M, Leitman P, Piratininga A, Ferreira da Costa A \& Forzza RC (2008) Bromeliaceae da Mata Atlântica brasileira: lista de espécies, distribuição e conservação. Rodriguésia 59: 209-258.

McCarty JP (2001) Ecological consequences of recent climate change. Conservation Biology 15: 320-331.

Medone P, Ceccarelli S, Parham PE, Figuera A \& Rabinovich JE (2015) The impact of climate change on the geographical distribution of two vectors of Chagas disease: implications for the force of infection. Philosophical Transactions of the Royal Society of London B: Biological Sciences 370: 1-12.

Melo EA \& Waechter JL (2018) Effect of vegetation matrix on diversity and distribution of epipetric bromeliads in a transitional region between Evergreen and Seasonal Forest. Flora 249: 77-85.

Miyamoto SNA \& Tardivo RC (2014) Nota taxonômica em Aechmea Ruiz \& Pav. (Bromeliaceae, Bromelioideae) e primeiro registro de Aechmea triangularis LB Sm. no estado do Paraná, Brasil. Rodriguésia 65: 555-561.

Mongiello CN \& Otero PA (2017) El perezoso de las plantas: el clavel del aire. Boletín Biológica 38: 13-16.

Nori J, Carrasco PA \& Leynaud GC (2014) Venomous snakes and climate change: ophidism as a dynamic problem. Climate Change 122: 67-80.

Núñez Bustos EO (2016) Mariposas diurnas (Lepidoptera: Papilionoidea \& Hesperioidea) de la Costa Atlántica Bonaerense, provincia de Buenos Aires, Argentina. In: Athor J \& Celsi CE (eds.) La Costa Atlántica de Buenos Aires, naturaleza y patrimonio cultural. Fundación de Historia Natural Félix de Azara, Ciudad Autónoma de Buenos Aires. Pp. 270-280.

Oeser R (1965) Southern Tillandsias. Journal of the Bromeliad Society 15: 8-12.

Parmesan C (2006) Ecological and evolutionary responses to recent climate change. Annual Review of Ecology, Evolution, and Systematics 37: 637669.

Parodi LR (1940) La distribución geográfica de los talares en la Provincia de Buenos Aires. Darwiniana 4: $33-56$.

Porembski S \& Barthlott W (1999) Pitcairnia feliciana: the only indigenous African bromeliad. Harvard Papers in Botany 4: 175-184.

Prigioni CM, Villalba Macias JS, Sappa A \& González JC (2018) Confirmación de la presencia del mono 
aullador negro (Alouatta caraya) (Mammalia, Primates, Atelidae) en el Uruguay. Acta Zoológica Platense 1: 1-11.

Reilly B (2004) Growing small grey-leafed Tillandsias. Journal of the Bromeliad Society 54: 59-64.

Reitz R (1983) Bromeliáceas e a malária-bromélia endémica. Flora Ilustrada Catarinense. Herbário Barbosa Rodrigues, Itajaí. 808p.

Schinini A, Wanderley MGL, Strehl T, Martins Z \& Moreira B (2008) Bromeliaceae. In: Zuloaga F, Morrone O \& Belgrano M (eds.) Catálogo de las plantas vasculares del Cono Sur (Argentina, sur de Brasil, Chile, Paraguay y Uruguay). Vol. 1. Monographs in Systematic Botany from the Missouri Botanical Garden 107, Saint Louis. Pp. 245-291.

Serrentino C, Prigioni CM \& Flores JC (2014) Señal climática en la Cuenca Binacional de la Laguna Merin: incremento pluviométrico intertreintenios genera posible estrés biótico. Consejo Uruguayo para las Relaciones Internacionales, Montevideo. $41 \mathrm{p}$.

Sierra EM, Hurtado RH \& Spescha L (1994) Corrimiento de las isoyetas anuales medias decenales en la Región Pampeana 1941-1990. Revista de Facultad de Agronomía 14: 139-144

Sierra EM \& Pérez SP (2006) Tendencias del régimen de precipitación y el manejo sustentable de los agroecosistemas: estudio de un caso en el noroeste de la provincia de Buenos Aires, Argentina. Revista de Climatología 6: 1-12.

Silva F, Alves M, Higuchi P \& Silva AC (2018) Impacto de mudanças climáticas sobre a distribuição geográfica potencial de Ilex paraguariensis. Rodriguésia 69: 2069-2079.

Silva Vieira K, Montenegro PFG, Santana GG \& da Silva Vieira WL (2018) Effect of climate change on distribution of species of common horned frogs in South America. PloS one 13: p.e0202813.

Smith LB \& Downs RJ (1977) Tillandsioideae (Bromeliaceae). Flora Neotropica 14: 663-1492.

Smith LB (1970) Notes on Bromeliaceae, XXXI. Phytologia 20: 121-183.

Smith LB (1972) Bromeliaceae. Flora del Uruguay 4: $1-31$.

Strehl T (2000) New taxons of Tillandsia subgenus
Anoplophytum (Bromeliaceae) from Rio Grande do Sul, Brazil. Iheringia, Série Botânica 54: 19-44.

Strehl T (2004) Novas espécies de Bromeliaceae do Rio Grande do Sul, Brasil. Vidalia 2: 19-25.

Strehl T \& Rohde G (1998) Novas bromélias do Rio Grande do Sul. Bromélia 5: 27-28.

Thiers B [continuously updated] Index Herbariorum: a global directory of public herbaria and associated staff. New York Botanical Garden's Virtual Herbarium. Available at <http://sweetgum.nybg. org/science/ih/>. Access on 24 January 2019.

Varella KLF (2011) Tillandsien aus Rio Grande do Sul: eine leidenschaft. Die Bromelie 1: 16-23.

Vervoorst FB (1967) Las comunidades vegetales de la Depresión del Salado. La Vegetación de la República Argentina, Serie Fitogeográfica $n^{\circ} 7$. Instituto Nacional de Tecnología Agropecuaria, Buenos Aires. 262p.

Villalba JS, Prigioni CM \& Sappa A (2018) Actualización de la distribución geográfica del oso hormiguero chico (Tamandua tetradactyla ssp.) (Mammalia, Myrmecophagidae) en el Uruguay. Acta Zoológica Platense 2: 1-8.

Walther GR (2010) Community and ecosystem responses to climatic change. Philosophical transactions of the Royal Society of London B: Biological Sciences 365: 2019-2024.

Walther GR, Post E, Convey P, Menzel A, Parmesan C, Beebee T, Fromentin J, Hoegh-Guldberg O \& Bairlein F (2002) Ecological responses to recent climate change. Nature 416: 389-395.

Wanderley MGL \& Martins SE (2007) Bromeliaceae. In: Wanderley MGL, Shepherd GJ, Melhem TS \& Giulietti AM (coord.); Melhem TS, Wanderley MGL, Martins SE, Jung-Mendaçolli SL, Shepherd GJ \& Kirizawa M (eds.) Flora fanerogâmica do estado de São Paulo. Instituto de Botânica, São Paulo. Vol. 5, pp. 39-162.

Zamorano M \& Scillato-Yané GJ (2008) Registro de Dasypus (Dasypus) novemcinctus (Mammalia, Dasypodidae) en el sudoeste de la provincia de Buenos Aires, Argentina. BioScriba 1: 17-26.

Zizka G, Schmidt M, Schulte K, Novoa P, Pinto R \& König K (2009) Chilean Bromeliaceae: diversity, distribution and evaluation of conservation status. Biodiversity and Conservation 18: 2449-2471. 